\title{
PUBLIC POLICY AND YOUTH \\ SMOKELESS TOBACCO USE
}

Frank J. Chaloupka

Michael Grossman

John A. Tauras

Working Paper 5524

\author{
NATIONAL BUREAU OF ECONOMIC RESEARCH \\ 1050 Massachusetts Avenue \\ Cambridge, MA 02138 \\ April 1996
}

This paper has been prepared for the annual meetings of the Midwest Economics Association, Chicago, IL, March 21, 1996. Support for this research was provided by the Robert Wood Johnson Foundation and the Centers for Disease Control and Prevention. We are indebted to Patrick O'Malley and Timothy Perry for providing the restricted Monitoring the Future data and to Robert L. Ohsfeldt for his helpful comments. This paper is part of NBER's research program in Health Economics. Any opinions expressed are those of the authors and not those of the National Bureau of Economic Research.

(C) 1996 by Frank J. Chaloupka, Michael Grossman and John A. Tauras. All rights reserved. Short sections of text, not to exceed two paragraphs, may be quoted without explicit permission provided that full credit, including (C) notice, is given to the source. 


\title{
PUBLIC POLICY AND YOUTH \\ SMOKELESS TOBACCO USE
}

\begin{abstract}
While much is known about the effects of prices and tobacco control policies on cigarette smoking, relatively little is known about their impact on smokeless tobacco use. This paper addresses these issues using data on smokeless tobacco use by adolescent males taken from the 1992, 1993, and 1994 Monitoring the Future Surveys. Site-specific smokeless tobacco tax data and several measures of limits on youth access to tobacco products are added to the survey data. Ordered probit methods are used to examine the impact of prices and tobacco control policies on the frequency of smokeless tobacco use among young males. Comparable two-part models are estimated for participation in smokeless tobacco use and for conditional smokeless tobacco demand. The estimates indicate that increases in smokeless tobacco taxes would lead to significant reductions in both the number of young men using smokeless tobacco and in the frequency of smokeless tobacco use. The average estimated price elasticity of smokeless tobacco

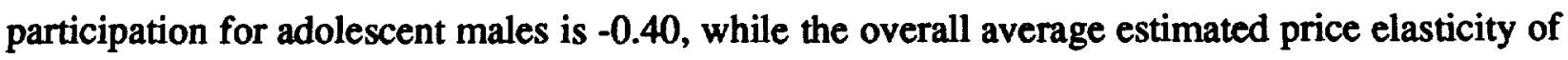
demand is $\mathbf{- 0 . 6 5}$. In addition, strong limits on youth access to smokeless tobacco products are found to be effective in reducing both participation in smokeless tobacco use and the frequency of smokeless tobacco use by young males.
\end{abstract}

Frank J. Chaloupka

Department of Economics, (M/C 144)

University of Illinois at Chicago

601 South Morgan Street

Chicago, IL 60607-7121 and NBER

John A. Tauras

Department of Economics (M/C 144)

University of Illinois at Chicago

601 South Morgan Street

Chicago, IL 60607-7121
Michael Grossman

Graduate Center

City University of New York 50 East 42nd Street, 17th Floor

New York, NY 10017-5405 and NBER 


\section{Introduction}

Tobacco use has gone through many stages in the United States. Prior to 1900, over $60 \%$ of all tobacco consumed in the U.S. took the form of smokeless tobacco. (U.S. Department of Health and Human Services (USDHHS), 1993) Cigarette smoking gained popularity in the early 1900 's and, by 1935 , more tobacco was being consumed in the form of cigarettes than all other tobacco products combined (USDHHS, 1993) As the popularity of cigarettes increased, the consumption of smokeless tobacco declined. This decline continued until the 1970's when smokeless tobacco consumption experienced a resurgence. This resurgence may have initially been spurred by the 1964 Surgeon General's report identifying smoking as a major cause of lung cancer. With the public's heightened awareness of the hazards of smoking, many people began consuming increased quantities of smokeless tobacco. The resurgence of smokeless tobacco consumption was further spurred by the tobacco industry's aggressive marketing of new smokeless tobacco products.

Smokeless tobacco consumption continued to increase at a rate of 10 to 11 percent per year (USDHHS, 1993) until 1986 when two significant events occurred: the Surgeon General's report entitled The Health Consequences of Using Smokeless Tobacco was released; and Congress passed the Comprehensive Smokeless Tobacco Act of 1986. The Surgeon General's report stated that smokeless tobacco use is not a safe substitute for cigarette smoking and represents a significant health risk. It also emphasized that smokeless tobacco can cause cancerous and noncancerous oral conditions, and can lead to nicotine addiction and dependence. The Comprehensive Smokeless Tobacco Act of 1986 banned advertising of 
smokeless tobacco products on television and radio, and required three health warnings be placed on smokeless tobacco packages.

Despite the actions taken in 1986 , which was followed by a three year decline in sales for smokeless tobacco products, the prevalence of smokeless tobacco use in the United States hasXbeenincreasing in recent years, particularly among young adult and adolescent males (USDHHS, 1993). From 1972 to 1991, total U.S. consumption of smokeless tobacco has risen from 99 million pounds per year to 125 million pounds (USDHHS, 1993). Almost $90 \%$ of all adolescent smokeless tobacco use is done by male youth (USDHHS, 1994). From 1970 to 1985 , the percentage of males age 16-19 using smokeless tobacco products increased by $321 \%$, from $1.4 \%$ to $5.9 \%$ (Marcus et al. 1989). After declining from 1986 through 1989, however, some recent surveys indicate that smokeless tobacco use among young males is again on the rise (USDHHS, 1994). These trends, coupled with the growing evidence on the addictive nature of smokeless tobacco (USDHHS, 1986), have led to an increased emphasis on policies aimed at discouraging the use of smokeless tobacco among adolescents.

This paper examines the effectiveness of several tobacco control policies in discouraging smokeless tobacco use among male adolescents. These policies include increased smokeless tobacco taxes (which result in higher smokeless tobacco prices), and limits on the availability of tobacco products to youths. The data used in this research are taken from the 1992,1993 , and 1994 survey of eighth, tenth, and twelfth grade students conducted by the University of Michigan's Institute for Social Research as part of the Monitoring the Future Project. This is a particularly interesting age group to study since 
addictive behaviors are most likely to become established during adolescence. As the recent Surgeon General's report concludes, nearly all first use of tobacco occurs before high school graduation (USDHHS, 1994), suggesting that if adolescents can be kept free of tobacco, most will never start using tobacco. Therefore, tobacco control policies aimed at this age group may be the most effective way of achieving and sustaining long run reductions in smokeless tobacco consumption in all segments of the population.

\section{Selected Review of Econometric Studies of Tobacco Demand}

Numerous econometric studies of cigarette demand have been published over the past several decades. ${ }^{1}$ Most of these have used diverse data and methods to estimate the effects of cigarette prices and taxes on smoking participation and cigarette consumption in the overall population and have concluded that higher cigarette prices reduce cigarette smoking. Relatively few of these econometric studies have focused on the price responsiveness of youth, with the majority of these concluding that cigarette demand among youths and young adults is more sensitive to price than cigarette demand among adults. ${ }^{2}$

${ }^{1}$ For comprehensive reviews of these studies, see the 1989 and 1994 Surgeon General's reports (USDHHS 1989 and 1994)

${ }^{2}$ The first studies of youth and young adult cigarette smoking concluded that demand was up to three times more sensitive to price than adult cigarette demand (Lewit and Coate, 1982; Lewit, Coate, and Grossman, 1981). Two recent studies, by Wasserman, et al. (1991) for youths, and by Chaloupka (1991) for adults, found little or no differences in the price responsiveness of demand. Unpublished recent studies, however, confirm that youth and young adult cigarette demand is more responsive to price than demand among adults (Chaloupka and Wechsler, 1995; Chaloupka and Grossman, 1995; and Evans and Farrelly, 1996). 
Unlike the numerous econometric studies published pertaining to cigarette demand, only two studies have examined the impact of price and tobacco control policies on smokeless tobacco use (Ohsfeldt and Boyle, 1994; Ohsfeldt, Boyle, and Capilouto, 1995). In the only published study, Ohsfeldt and Boyle (1994) estimated smokeless tobacco participation equations for adults (age 16+) using state-level aggregates constructed from the 1985 Current Population Survey. They estimated an own-tax elasticity of demand for adults of -0.55 , which is at the higher end of the range when compared to the elasticities obtained from studies of adult cigarette smoking. In addition, they estimated that the cross-tax elasticity of any smokeless tobacco use with respect to cigarettes was 0.49 . Given that cigarette taxes were increasing relative to smokeless tobacco taxes throughout the early 1980 's, Ohsfeldt and Boyle concluded that the increase in smokeless tobacco use during this period was, in part, the result of substitution away from cigarettes towards smokeless tobacco products.

Expanding on their original study, Ohsfeldt, Boyle, and Capilouto (1995) used the individual level data from the September 1985 Current Population Survey to estimate cigarette smoking and smokeless tobacco participation equations for males ages 16 and older. In addition, for males, they estimated separate participation equations for the $16-24$ year old and 25 and older samples. They found a negative and significant effect of smokeless tobacco taxes on smokeless tobacco use among males, with an estimated own-tax elasticity of any smokeless tobacco use of -0.15 . However, they find that restrictive laws on cigarette smoking have no impact on smokeless tobacco use. In addition, they estimated cross-tax elasticities of any smokeless tobacco use with respect to cigarettes of 0.10 and with respect to 
beer of 0.04 . Finally, they generally estimated larger own- and cross-tax elasticities for younger males relative to older males.

While the recent study by Ohsfeldt, Boyle, and Capilouto (1995) examines the impact of smokeless tobacco taxes on smokeless tobacco use among young males, it uses data from 1985. As they note, this data pre-dates the Comprehensive Smokeless Tobacco Act of 1986, which they suggest may lead to different conclusions about the impact of smokeless tobacco taxes on smokeless tobacco use. Similarly, it pre-dates the widespread passage of legislation at the state level resulting from the Synar amendment which restricts youth access to all tobacco products. Thus, this study is the first to examine the impact of smokeless tobacco taxes on young males' smokeless tobacco use after the Comprehensive Smokeless Tobacco Act of 1986 , as well as to examine the effects of policies restricting youth access to tobacco products.

\section{Data and Methods}

The data for this study are taken from the 1992, 1993, and 1994 survey of eighth, tenth, and twelfth grade students conducted by the Institute for Social Research (ISR) at the University of Michigan as part of the Monitoring the Future Project. ISR has collected a nationally representative sample of 15,000 to 19,000 high school seniors each year since 1975. In 1991, ISR began conducting an annual survey of similar numbers of eighth and tenth grade students. These surveys focus on the use of alcohol, tobacco, and illicit drugs among youths. Given the nature of the data being collected, extensive efforts are made by 
ISR to ensure that the data collected are informative. For example, parents are not present during the completion of the surveys, and are not informed about their child's responses. By special agreement, ISR provided a restricted data set containing variables reflecting youth tobacco use and identifiers for each respondent's county of residence. Data on a variety of socioeconomic and demographic information was also provided.

In each year, approximately half of the eighth and tenth grade samples and about onesixth of the twelfth grade samples were asked about their current and past smokeless tobacco use. These data were used to construct three alternative dependent variables: frequency of smokeless tobacco consumption, participation in smokeless tobacco use, and average monthly smokeless tobacco consumption. The first measure, constructed from the categorical data collected in the survey, is an ordered level of smokeless tobacco use variable, reflecting the number of times the youth consumed smokeless tobacco in the previous thirty days. This variable takes on a value of zero for youths who did not use smokeless tobacco in the 30 days prior to the survey, one for light users (used once or twice in the previous 30 days), two for moderate users (used one to five times per week in the previous 30 days), and three for heavy users (used once or more per day for the previous 30 days). The second variable (participation in smokeless tobacco use) is a dichotomous indicator equal to one for youths who indicate that they used smokeless tobacco in the 30 days prior to the survey, and is equal to zero otherwise. The final dependent variable is a "continuous" measure of monthly smokeless tobacco consumption, based on the midpoints of the categorical responses reflecting smokeless tobacco use in the 30 days before the survey. This variable takes on values of $0,1.5,6,16$, and 30 , corresponding to the five categorical responses from the 
survey. While not ideal, this continuous measure will be helpful in estimating the tax elasticity of smokeless tobacco demand among adolescent male users.

Based on the survey data, a variety of independent variables were constructed to control for other factors affecting smokeless tobacco demand. These include: the age of the respondent, in years; average weekly income from all sources, in 1982-1984 dollars (employment, allowances, etc.); separate indicators for youths surveyed in 1993 and 1994; an indicator for youths surveyed in the eighth/tenth grade survey; indicators of race/ethnicity (white-omitted, black, and others); indicators of parental education (less than high school graduate, high school graduate-omitted, and more than high school graduate for mother and father separately); indicators of family structure (live alone, mother only parent present, father only parent present, both parents present-omitted, no parents present - live with other relative, and other); indicators of mother's work status while youth was growing up (mother worked part-time, mother worked full time, and mother did not work-omitted); an indicator for youths with siblings; average number of hours worked weekly; an indicator for youths living in rural areas; and an indicator for frequency of participation in religious services (none-omitted, infrequent participation, and frequent participation).

Based on each respondent's county of residence, smokeless tobacco tax and tobacco control policy data were added to the survey data. Measures of state level excise taxes on smokeless tobacco were obtained from the Tobacco Institute's annual Tax Burden on Tobacco. These tax rates are expressed as a percentage of the wholesale price of the 
product. ${ }^{3}$ The tobacco control policy variables include: the state minimum legal purchase age for smokeless tobacco; a dichotomous indicator for states with restrictions on the distribution of free samples of tobacco products to youths; a dichotomous indicator for states that have tobacco licensing provisions that penalize tobacco vendors for furnishing tobacco products to minors, with additional penalties of license revocation for subsequent offenses; and a dichotomous indicator for states that require a sign indicating the minimum purchase age for tobacco products be posted where those products are sold.

Given that few young women consume smokeless tobacco products, the sample was restricted to young males. ${ }^{4}$ After eliminating respondents with missing or inconsistent data, a sample of 19,581 young males was obtained. Table One contains brief definitions and the descriptive statistics for the dependent and independent variables employed.

Given the limited nature of the dependent variables, ordinary least squares techniques are not appropriate. Instead, two alternative approaches are used. For the ordered frequency of smokeless tobacco use variable, ordered probit methods are employed. These methods will provide a general sense of the relationship between smokeless tobacco taxes and limits on youth access to tobacco products and youth smokeless tobacco consumption. To more clearly examine these relationships, a two-part model of smokeless tobacco demand is

${ }^{3}$ Alabama and Alaska impose excise taxes on smokeless tobacco products. None of the youths surveyed resided in Alaska. Due to the lack of information on wholesale or retail smokeless tobacco prices, an estimate of the tax as a percentage of wholesale price could not be estimated for Alabama. Consequently, youths residing in Alabama were dropped from the sample.

${ }^{4}$ In the 1992 through 1994 MTF data, smokeless tobacco use participation rates for young females were approximately two percent, compared to over 15 percent for young males. 
estimated based on the model developed by Cragg (1971). In the first step, probit methods are used to estimate a smokeless tobacco use participation equation. In the second step, ordinary least squares methods are used to estimate average monthly smokeless tobacco consumption by users, where the dependent variable is the natural logarithm of the continuous monthly consumption measure. The same set of independent variables is included in both equations.

\section{Results}

Ordered probit estimates for the frequency of smokeless tobacco consumption are presented in Table Two. Four alternative models are estimated. Model One contains the estimates from a limited specification which includes the smokeless tobacco tax, income, age, and the indicators of race, rural residence, religiosity, year and grade. Model Two contains the estimates from a full specification which adds the measures of family structure, parental education, maternal working, youth average hours worked, and marital status. Models Three and Four add the four variables capturing limits on youth access to tobacco products to the variables included in Models One and Two. Tables Three and Four contain comparable estimates for the two-part model. Table Three contains the probit estimates for smokeless tobacco participation, and Table Four contains the least squares estimates of conditional smokeless tobacco demand.

The smokeless tobacco tax has a negative and statistically significant impact in all equations estimated for the frequency of smokeless tobacco consumption and for participation in smokeless tobacco use. In addition, the smokeless tobacco tax has a negative, albeit 
generally statistically insignificant impact on smokeless tobacco use by users. These estimates clearly show that increases in smokeless tobacco taxes would reduce the frequency of smokeless tobacco use by adolescent males, and would reduce the probability that a male youth consumes smokeless tobacco products. However, the estimates do not provide strong evidence that higher smokeless tobacco taxes would have a significant impact on the consumption of smokeless tobacco by young male users. ${ }^{5}$

Table Five contains the estimated tax elasticities from the two-part models of smokeless tobacco use by young males. The estimates of the overall tax elasticities of male youth smokeless tobacco demand range from -0.060 to -0.110 . Almost two-thirds of the effect of the tax on young males' smokeless tobacco use is on the decision to use smokeless tobacco products (the average participation elasticity is -0.052 ). The remainder of the effect is on the average smokeless tobacco consumption among users (average elasticity of -0.032 ), although this estimate is based on mostly insignificant estimates of the effect of the tax on demand. These estimates are somewhat below Ohsfeldt, Boyle, and Capilouto's (1995) estimates for young males ages 16 through 24 years obtained using 1985 data. This suggests that the price responsiveness of smokeless tobacco use by young males may be falling over time. This could be the result of the stronger limits on youth access to tobacco products in place during the 1992 through 1994 period covered by this study. That is, a comparable

\footnotetext{
${ }^{5}$ In an effort to estimate the potential substitutability/complementarity of smokeless tobacco products and cigarettes, models including the real price of cigarettes were also estimated. Unfortunately, very unstable estimates resulted. Belsley, Ku and Welsch (1980) collinearity diagnostics indicated that the estimates for the smokeless tobacco tax, cigarette price, and time dummy variables were confounded by the presence of multicollinearity in these models.
} 
increase in the smokeless tobacco tax in the more recent period results in a smaller increase in the full price of smokeless tobacco for underage youths than it did in 1985 when there were relatively fewer limits on youth access. ${ }^{6}$

Estimated price elasticities of smokeless tobacco demand by young males are also presented in Table Five. Two assumptions are made in converting the tax elasticities to price elasticities. The first is that a one cent increase in smokeless tobacco taxes will result in a one cent increase in smokeless tobacco prices. This is consistent with much of the evidence on the effects of cigarette taxes on cigarette prices. For example, Barnett, Keeler, and $\mathrm{Hu}$, (forthcoming) conclude that a one cent increase in the federal cigarette tax would raise cigarette prices by 1.04 cents. The second assumption is that smokeless tobacco taxes are approximately 13 percent of the retail prices of smokeless tobacco products (Connolly, 1994). Given these assumption, the average overall price elasticity of young males' smokeless tobacco demand is -0.650 . This suggests that increases in the prices of smokeless tobacco products would significantly reduce the consumption of these products by young males. For example, a ten percent increase in price would reduce male youth smokeless tobacco consumption by about 6.5 percent. Larger increases in price would lead to even larger reductions in male youth consumption. This estimated price elasticity of young males' smokeless tobacco demand is about half the -1.25 Chaloupka and Grossman (1995) estimate for cigarette demand by young males. Nevertheless, it is well above the consensus estimate

\footnotetext{
${ }^{6}$ Using data from the 1982 and 1989 Monitoring the Future Surveys of High School seniors, Laixuthai and Chaloupka (1993) made a similar argument with respect to the price elasticity of youth alcohol demand after the change to a uniform minimum legal drinking age of 21 years.
} 
of the price elasticity of cigarette demand by adults.

In general, the variables capturing limits on youth access to tobacco products indicate that strong limits reduce smokeless tobacco use among young males. The minimum legal purchase age for smokeless tobacco products and the dichotomous indicator of strong tobacco licensing provisions are both found to have a negative and statistically significant impact in all of the equations estimated for each of the three measures of smokeless tobacco consumption. Restrictions on the distribution of free samples and requiring signs indicating the minimum legal purchase age also have a negative and statistically significant impact in the four models for the frequency of smokeless tobacco use and for participation in smokeless tobacco use, but have a statistically insignificant impact on smokeless tobacco use by users. These estimates clearly show that policies aimed at limiting youth access to tobacco products significantly reduce smokeless tobacco use among young males.

Young males with higher real weekly incomes, either from employment or from other sources, are significantly more likely to use smokeless tobacco products, and to consume more often than young males with lower incomes. This positive relationship between income and smokeless tobacco consumption contrasts with much of the recent empirical evidence for cigarette demand that suggests that cigarette smoking is an economically inferior behavior for adults. (i.e. Wasserman, et al., 1991). However, it is consistent with Chaloupka and Grossman's (1995) estimates for youth cigarette smoking.

With respect to race and ethnicity, young black males are much less likely to use smokeless tobacco products. Other non-white young males are also less likely to use smokeless tobacco products than whites, but are more likely to use than blacks. Similarly, 
among users young black males use significantly less than other young males. Older male youths are more likely to use smokeless tobacco products and consume more often than younger male youths. Holding age constant, youths in eighth or tenth grade were more likely to use smokeless tobacco products and to consume more frequently than high school seniors. Young males with a stronger attachment to religion, as measured by attendance at religious services, are much less likely to use smokeless tobacco products, and consume less often than those with little or no attachment. Young males living in rural areas were significantly more likely to consume smokeless tobacco products and to consume more frequently than those living in urban and suburban areas.

With respect to family structure, young males who live alone are most likely to use smokeless tobacco products and consume more often, while those who live with both parents are least likely to use and consume least often. Male youths whose mothers worked when they were younger are significantly more likely to use smokeless tobacco and consume more often than youths whose mothers stayed home. Engaged or married male youths are significantly less likely to use smokeless tobacco products than are unattached youths. Finally male youth smokeless tobacco consumption is inversely related to paternal education, but mixed results are estimated with respect to maternal education.

\section{Discussion}

The results described above indicate that tobacco control policies, including higher smokeless tobacco taxes, higher minimum legal purchase ages for tobacco products, strong 
tobacco licensing provisions, restrictions on the distribution of free samples of tobacco products, and the posting of minimum purchase age signs are effective in reducing adolescent male smokeless tobacco use. The average overall estimated price elasticity of smokeless tobacco demand for male youths was -0.65 . This implies that large increases in smokeless tobacco excise taxes, by significantly raising price, would lead to sharp reductions in smokeless tobacco use among young males. Recently, substantial increases in federal smokeless tobacco excise tax rates have been discussed as a source of revenues to finance U.S. health care reform. For example, proposed increases in federal smokeless tobacco taxes were contained in the Clinton Administration's Health Security Act of 1993. Had these increases been enacted, the federal tax on snuff, for example, would have risen from the 1994 level of 2.7 cents per tin of snuff to 96 cents per tin. This would have been an increase in the federal snuff tax of nearly 3500 percent. Comparable federal tax increases were proposed for other smokeless tobacco products. Given the relatively small share of the federal tax in the price of smokeless tobacco products (Connolly (1994) estimates this to be approximatel one percent), and assuming that tax increases are fully passed on, federal tax increases of this magnitude on all smokeless tobacco products would raise the prices of these products by about 135 percent. Based on the estimates presented above, this would lead to a 40 to 68 percent reduction in the number of young males using smokeless tobacco products. 


\section{References}

Barnett, P.G., T.E. Keeler, and T.W. Hu, "Oligopoly Structure and the Incidence of Cigarette Ecise Taxes," Journal of Public Economics, forthcoming.

Belsley, D., E. Kuh, and R. Welsch, Regression Diagnostics: Identifying Influential Data and Sources of Collinearity, New York: Wiley, 1980.

Chaloupka, F.J., "Rational Addictive Behavior and Cigarette Smoking,' Journal of Political Economy, 99: 722-42, 1991.

Chaloupka, F.J., and H. Wechsler, "Price, Tobacco Control Policies, and Smoking Among Young Adults," National Bureau of Economic Research Working Paper Number 5012, February, 1995.

Chaloupka, F.J., and M. Grossman, "Price, Tobacco Control Policies and Youth Smoking," manuscript presented at the annual meetings of the Western Economics Association International, San Diego, CA, July 1995.

Connolly, G.N., Testimony before the House Committee on Ways and Means, House of Representatives, 103rd Congress, 1st Session. Serial No. 103-61. Financing Provisions of the Administration's Health Security Act and Other Health Reform Proposals. U.S. Government Printing Office, 1994

Cragg, J.G., "Some Statistical Models for limited Dependent Variables with Application to the Demand for Durable Goods," Econometrica, 39, No.5, 1971.

Evans, W.N., and M.C. Farrelly, "The Compensating Behavior of Smokers: Taxes, Tar, and Nicotine," manuscript presented at the annual meetings of the Allied Social Science Associations, San Francisco, CA, January, 1996.

Keeler, T.E., T.W. Hu, P.G. Barnett, "Oligopoly Structure and the Incidence of Cigarette Taxes," Journal of Political Economics, 1995.

Laixuthai, A., and F.J. Chaloupka, "Youth Alcohol Use and Public Policy," Contemporary Policy Issues, 11: 69-81, 1993.

Lewit, E.M., and D. Coate, "The Potential for Using Excise Taxes to Reduce Smoking," Journal of Health Economics, 1: 121-45, 1982.

Lewit, E.M., D. Coate, and M. Grossman, "The Effects of Government Regulation on Teenage Smoking," Journal of Law and Economics, 24: 545-69, 1981

Marcus, A.C., L.A. Crane, D.R. Shopland, and W.R. Lynn, "Use of Smokeless Tobacco in 
the United States: Recent Estimates from the Current Population Survey, " $\mathrm{NCI}$ Monographs, 8: $17-24,1989$

Ohsfeldt, R.L., and R.G. Boyle, "Tobacco Excise Taxes and Rates of Smokeless Tobacco Use in The U.S.: An Explanatory Ecological Analysis," Tobacco Control, 3: 316-323, 1994

Ohsfeldt, R.L., R.G. Boyle, and E. Capilouto, "Effects of Tobacco Excise Taxes on the Use of Smokeless Tobacco Products in the U.S. ", manuscript, 1995.

Tobacco Institute, The Tax Burden on Tobacco, Washington D.C.: Tobacco Institute, 1995.

U.S. Department of Health and Human Services, The Health Consequences of Using Smokeless Tobacco: A Report of the Advisory Committee to the Surgeon General, Bethesda Maryland: National Cancer Institute, 1986.

U.S. Department of Health and Human Services, Reducing the Health Consequences of Smoking: 25 Years of Progress. A Report of the Surgeon General, Rockville, Maryland: U.S. Department of Health and Human Services, Public Health Service, Centers for Disease Control, Center for Chronic Disease Prevention and Health Promotion, Office on Smoking and Health, 1989.

U.S. Department of Health and Human Services,, Smokeless Tobacco or Health: An International Perspective, Washington, D.C.: Public Health Service, National Institutes on Health, 1993.

U.S. Department of Health and Human Services, Preventing Tobacco Use Among Young People: A Report to the Surgeon General, Atlanta Georgia: Public Health Service, Center for Disease Control and Prevention, National Center for Chronic Disease Prevention and Health Promotion, Office on Smoking and Health, 1994.

Wasserman, J., W.G. Manning, J.P. Newhouse, and J.D. Winkler, "The Effects of Excise Taxes and Regulation on Cigarette Smoking," Journal of Health Economics, 10: 43-64, 1991. 


\section{Table One}

\section{Variable Definitions and Descriptive Statistics}

\begin{tabular}{|c|c|}
\hline Variable & Definition, Mean $(\mu)$, and Standard Deviation $(\sigma)$ \\
\hline $\begin{array}{l}\text { Frequency of Smokeless Tobacco } \\
\text { Use }\end{array}$ & $\begin{array}{l}\text { Ordered variable equal to zero for nonusers, one for light users one } \\
\text { or two times in past month), two for moderate users (one to five } \\
\text { times per week), and three for heavy users (once a day or more). } \\
\mu=0.28, \sigma=0.73\end{array}$ \\
\hline Smokeless Tobacco Participation & $\begin{array}{l}\text { Dichotomous indicator equal to one if male youth reports consuming } \\
\text { smokeless tobacco in the past } 30 \text { days, equal to zero otherwise. } \\
\mu=0.15, \sigma=0.36\end{array}$ \\
\hline $\begin{array}{l}\text { Smokeless Tobacco Consumption } \\
\text { by Users }\end{array}$ & $\begin{array}{l}\text { Natural logarithm of number of times smokeless tobacco was used in } \\
\text { the month prior to the survey (users only). } \mu=0.73, \sigma=1.47\end{array}$ \\
\hline Smokeless Tobacco Tax & $\begin{array}{l}\text { State level tax on smokeless tobacco, expressed as a percentage of } \\
\text { wholesale price of the product. } \mu=11.26, \sigma=10.90\end{array}$ \\
\hline Minimum Purchase Age & $\begin{array}{l}\text { State minimum legal purchase age, in years, for tobacco products. } \\
\mu=17.99, \sigma=0.11\end{array}$ \\
\hline $\begin{array}{l}\text { Restriction on Distribution of Free } \\
\text { Samples }\end{array}$ & $\begin{array}{l}\text { Dichotomous indicator for states restricting the distribution of free } \\
\text { samples of tobacco products to youths. } \mu=0.58, \sigma=0.49\end{array}$ \\
\hline Tobacco Licensing Provisions & $\begin{array}{l}\text { Dichotomous indicator for states that have tobacco licensing } \\
\text { provisions that penalize tobacco vendors for furnishing tobacco } \\
\text { products to minors. } \mu=0.92, \sigma=0.28\end{array}$ \\
\hline Minimum Purchase Age Signs & $\begin{array}{l}\text { Dichotomous indicator for states that require a sign indicating the } \\
\text { minimum purchase age for tobacco products be posted where those } \\
\text { products are sold. } \mu=0.79, \sigma=0.41\end{array}$ \\
\hline Black & $\begin{array}{l}\text { Dichotomous indicator equal to one for blacks and zero otherwise. } \\
\mu=0.10, \sigma=0.30\end{array}$ \\
\hline Other Race & $\begin{array}{l}\text { Dichotomous indicator equal to one for individuals who are not black } \\
\text { or white and zero otherwise. } \mu=0.19, \sigma=0.39\end{array}$ \\
\hline Age & Age, in years. $\mu=15.61, \sigma=1.59$ \\
\hline Infrequent Religious Attendance & $\begin{array}{l}\text { Dichotomous indicator equal to one for male youths who attend } \\
\text { religious services infrequently and zero otherwise. } \mu=0.47, \sigma=0.50\end{array}$ \\
\hline Frequent Religious Attendance & $\begin{array}{l}\text { Dichotomous indicator equal to one for male youths who attend } \\
\text { religious services frequently and zero otherwise. } \mu=0.38, \sigma=0.48\end{array}$ \\
\hline Rural & $\begin{array}{l}\text { Dichotomous indicator equal to one for male youths residing in rural } \\
\text { communities and zero otherwise. } \mu=0.24, \sigma=.43\end{array}$ \\
\hline
\end{tabular}




\begin{tabular}{|c|c|}
\hline Variable & Definition, Mean $(\mu)$, and Standard Deviation ( $\sigma)$ \\
\hline Live Alone & $\begin{array}{l}\text { Dichotomous indicator equal to one for male youths who live alone } \\
\text { and zero otherwise. } \mu=0.004, \sigma=0.06\end{array}$ \\
\hline Father Only & $\begin{array}{l}\text { Dichotomous indicator equal to one for male youths in families with } \\
\text { the father the only parent present and zero otherwise. } \mu=0.04 \text {, } \\
\sigma=0.19\end{array}$ \\
\hline Mother Only & $\begin{array}{l}\text { Dichotomous indicator equal to one for male youths in families with } \\
\text { the mother the only parent present and zero otherwise. } \mu=0.14 \text {, } \\
\sigma=0.34\end{array}$ \\
\hline Other Family Structure & $\begin{array}{l}\text { Dichotomous indicator equal to one for male youths in families with } \\
\text { neither parent present and zero otherwise. } \mu=0.03, \sigma=0.16\end{array}$ \\
\hline Siblings & $\begin{array}{l}\text { Dichotomous indicator equal to one for male youths with at least one } \\
\text { sibling and zero otherwise. } \mu=0.77, \sigma=0.42\end{array}$ \\
\hline $\begin{array}{l}\text { Father Less Than High School } \\
\text { Graduate }\end{array}$ & $\begin{array}{l}\text { Dichotomous indicator equal to one for male youths with fathers who } \\
\text { did not graduate from high school and zero otherwise. } \\
\mu=0.12, \sigma=0.32\end{array}$ \\
\hline $\begin{array}{l}\text { Father More Than High School } \\
\text { Graduate }\end{array}$ & $\begin{array}{l}\text { Dichotomous indicator equal to one for male youths with fathers who } \\
\text { have more than a high school education and zero otherwise. } \\
\mu=0.60, \sigma=0.49\end{array}$ \\
\hline $\begin{array}{l}\text { Mothers Less Than High School } \\
\text { Graduate }\end{array}$ & $\begin{array}{l}\text { Dichotomous indicator equal to one for male youths with mothers } \\
\text { who did not graduate from high school and zero otherwise. } \\
\mu=0.10, \sigma=0.30\end{array}$ \\
\hline $\begin{array}{l}\text { Mothers More Than High School } \\
\text { Graduate }\end{array}$ & $\begin{array}{l}\text { Dichotomous indicator equal to one for male youths with mothers } \\
\text { who have more than a high school education and zero otherwise. } \\
\mu=0.58, \sigma=0.49\end{array}$ \\
\hline Not Single & $\begin{array}{l}\text { Dichotomous indicator equal to one for male youths who are either } \\
\text { married or engaged and zero otherwise. } \mu=0.01, \sigma=0.09\end{array}$ \\
\hline Mother Worked Part-time & $\begin{array}{l}\text { Dichotomous indicator equal to one for male youths whose mothers } \\
\text { worked part-time while they were growing up and zero otherwise. } \\
\mu=0.21, \sigma=0.41\end{array}$ \\
\hline Mother Worked Full-time & $\begin{array}{l}\text { Dichotomous indicator equal to one for male youths whose mothers } \\
\text { worked full-time while they were growing up and zero otherwise. } \\
\mu=0.59, \sigma=0.49\end{array}$ \\
\hline Average Hours Worked & Average hours worked weekly for pay. $\mu=6.15, \sigma=9.16$ \\
\hline Real Weekly Income & $\begin{array}{l}\text { Average weekly income, in dollars, from employment and other } \\
\text { sources, deflated by the national Consumer Price Index, 1982-84=1. } \\
\mu=31.4, \sigma=36.5\end{array}$ \\
\hline
\end{tabular}




\begin{tabular}{||l|l||}
\hline \hline Variable & Definition, Mean $(\mu)$, and Standard Deviation $(\sigma)$ \\
\hline \hline Grade 8 or 10 & $\begin{array}{l}\text { Dichotomous indicator equal to one for male youths surveyed in the } \\
\text { eighth/tenth grade survey and zero otherwise. } \mu=0.87, \sigma=0.34\end{array}$ \\
\hline Year $=1993$ & $\begin{array}{l}\text { Dichotomous indicator equal to one for male youths surveyed in } 1993 \\
\text { and zero otherwise. } \mu=0.33, \sigma=0.47\end{array}$ \\
\hline Year $=1994$ & $\begin{array}{l}\text { Dichotomous indicator equal to one for male youths surveyed in } 1994 \\
\text { and zero otherwise. } \mu=0.35, \sigma=0.48\end{array}$ \\
\hline
\end{tabular}


Table 2

Ordered Level of Smokeless Tobacco Use*

\begin{tabular}{|c|c|c|c|c|}
\hline Independent Variables & Model One & Model Two & Model Three & Model Four \\
\hline Smokeless Tobacco Tax & $\begin{array}{l}-0.004 \\
(-4.29)\end{array}$ & $\begin{array}{l}-0.004 \\
(-3.93)\end{array}$ & $\begin{array}{l}-0.003 \\
(-2.77)\end{array}$ & $\begin{array}{l}-0.003 \\
(-2.49)\end{array}$ \\
\hline Minimum Purchase Age & & & $\begin{array}{l}-0.264 \\
(-2.64)\end{array}$ & $\begin{array}{l}-0.232 \\
(-2.30)\end{array}$ \\
\hline $\begin{array}{l}\text { Restriction on Distribution of } \\
\text { Free Samples }\end{array}$ & & & $\begin{array}{l}-0.043 \\
(-1.91)\end{array}$ & $\begin{array}{l}-0.041 \\
(-1.80)\end{array}$ \\
\hline Tobacco Licensing Provisions & & & $\begin{array}{l}-0.189 \\
(-5.04)\end{array}$ & $\begin{array}{l}-0.187 \\
(-4.99)\end{array}$ \\
\hline Minimum Purchase Age Signs & & & $\begin{array}{l}-0.111 \\
(-4.17)\end{array}$ & $\begin{array}{l}-0.105 \\
(-3.92)\end{array}$ \\
\hline Black & $\begin{array}{l}-0.899 \\
(-15.94)\end{array}$ & $\begin{array}{l}-0.970 \\
(-16.79)\end{array}$ & $\begin{array}{l}-0.890 \\
(-15.83)\end{array}$ & $\begin{array}{l}-0.966 \\
(-16.65)\end{array}$ \\
\hline Other Race & $\begin{array}{l}-0.200 \\
(-6.62)\end{array}$ & $\begin{array}{l}-0.240 \\
(-7.66)\end{array}$ & $\begin{array}{r}-0.190 \\
(-6.23)\end{array}$ & $\begin{array}{r}-0.227 \\
(-7.26)\end{array}$ \\
\hline Age & $\begin{array}{l}0.107 \\
(10.4)\end{array}$ & $\begin{array}{l}0.102 \\
(9.75)\end{array}$ & $\begin{array}{r}0.107 \\
(10.39)\end{array}$ & $\begin{array}{l}0.102 \\
(9.75)\end{array}$ \\
\hline Real Weekly Income & $\begin{array}{c}0.005 \\
(15.75)\end{array}$ & $\begin{array}{c}0.004 \\
(11.13)\end{array}$ & $\begin{array}{r}0.004 \\
(15.68)\end{array}$ & $\begin{array}{c}0.004 \\
(11.05)\end{array}$ \\
\hline Grade 8 or 10 & $\begin{array}{l}0.343 \\
(7.83)\end{array}$ & $\begin{array}{r}0.332 \\
(7.39)\end{array}$ & $\begin{array}{l}0.349 \\
(7.93)\end{array}$ & $\begin{array}{r}0.338 \\
(7.50)\end{array}$ \\
\hline Year $=1993$ & $\begin{array}{l}-0.116 \\
(-4.07)\end{array}$ & $\begin{array}{l}-0.110 \\
(-3.88)\end{array}$ & $\begin{array}{l}-0.100 \\
(-3.50)\end{array}$ & $\begin{array}{r}-0.097 \\
(-3.37)\end{array}$ \\
\hline Year $=1994$ & $\begin{array}{l}-0.068 \\
(-2.45)\end{array}$ & $\begin{array}{l}-0.063 \\
(-2.27)\end{array}$ & $\begin{array}{l}-0.061 \\
(-2.14)\end{array}$ & $\begin{array}{l}-0.058 \\
(-2.04)\end{array}$ \\
\hline Rural & $\begin{array}{l}0.385 \\
(15.9)\end{array}$ & $\begin{array}{c}0.362 \\
(14.68)\end{array}$ & $\begin{array}{r}0.378 \\
(15.62)\end{array}$ & $\begin{array}{r}0.356 \\
(14.45)\end{array}$ \\
\hline $\begin{array}{l}\text { Infrequent Religious } \\
\text { Attendance }\end{array}$ & $\begin{array}{l}0.010 \\
(0.32)\end{array}$ & $\begin{array}{r}0.030 \\
(0.96)\end{array}$ & $\begin{array}{l}0.006 \\
(0.20)\end{array}$ & $\begin{array}{l}0.026 \\
(0.82)\end{array}$ \\
\hline $\begin{array}{l}\text { Frequent Religious } \\
\text { Attendance }\end{array}$ & $\begin{array}{l}-0.149 \\
(-4.49)\end{array}$ & $\begin{array}{l}-0.095 \\
(-2.80)\end{array}$ & $\begin{array}{r}-0.152 \\
(-4.58)\end{array}$ & $\begin{array}{l}-0.099 \\
(-2.90)\end{array}$ \\
\hline
\end{tabular}




\begin{tabular}{|c|c|c|c|c|}
\hline Independent Variables & Model One & Model Two & Model Three & Model Four \\
\hline Live Alone & & $\begin{array}{r}0.397 \\
(2.57)\end{array}$ & & $\begin{array}{l}0.393 \\
(2.54)\end{array}$ \\
\hline Father Only & & $\begin{array}{r}0.210 \\
(3.85)\end{array}$ & & $\begin{array}{l}0.208 \\
(3.81)\end{array}$ \\
\hline Mother Only & & $\begin{array}{r}0.081 \\
(2.40)\end{array}$ & & $\begin{array}{l}0.083 \\
(2.46)\end{array}$ \\
\hline Other Family Structure & & $\begin{array}{l}0.188 \\
(2.69)\end{array}$ & & $\begin{array}{l}0.188 \\
(2.68)\end{array}$ \\
\hline Siblings & & $\begin{array}{l}-0.032 \\
(-1.16)\end{array}$ & & $\begin{array}{l}-0.028 \\
(-1.01)\end{array}$ \\
\hline $\begin{array}{l}\text { Father Less Than High } \\
\text { School Graduate }\end{array}$ & & $\begin{array}{l}0.143 \\
(3.70)\end{array}$ & & $\begin{array}{l}0.142 \\
(3.65)\end{array}$ \\
\hline $\begin{array}{l}\text { Father More Than High } \\
\text { School Graduate }\end{array}$ & & $\begin{array}{r}-0.060 \\
(-2.20)\end{array}$ & & $\begin{array}{r}-0.057 \\
(-2.10)\end{array}$ \\
\hline $\begin{array}{l}\text { Mother Less Than High } \\
\text { School Graduate }\end{array}$ & & $\begin{array}{r}-0.033 \\
(-0.80)\end{array}$ & & $\begin{array}{l}-0.036 \\
(-0.85)\end{array}$ \\
\hline $\begin{array}{l}\text { Mother More Than High } \\
\text { School Graduate }\end{array}$ & & $\begin{array}{l}-0.050 \\
(-1.94)\end{array}$ & & $\begin{array}{r}-0.051 \\
(-1.96)\end{array}$ \\
\hline Not Single & & $\begin{array}{l}0.062 \\
(0.53)\end{array}$ & & $\begin{array}{l}0.058 \\
(0.49)\end{array}$ \\
\hline Mother Worked Part-time & & $\begin{array}{c}0.018 \\
(0.52)\end{array}$ & & $\begin{array}{l}0.021 \\
(0.60)\end{array}$ \\
\hline Mother Worked Full-time & & $\begin{array}{l}0.117 \\
(3.98)\end{array}$ & & $\begin{array}{l}0.116 \\
(3.93)\end{array}$ \\
\hline Average Hours Worked & & $\begin{array}{c}0.002 \\
(1.48)\end{array}$ & & $\begin{array}{l}0.002 \\
(1.57)\end{array}$ \\
\hline
\end{tabular}

- All equations also include an intercept. Asymptotic t-ratios are in parentheses. The critical values for the tratios are $2.58(2.33), 1.96(1.64)$, and $1.64(1.28)$ at the one, five, and ten percent significance levels respectively, based on a two-tailed (one-tailed) test. All equations, based on a Chi-square test of $-2 * \log$ likelihood ratio are significant at the one percent significance level. 
Table 3

Smokeless Tobacco Participation*

\begin{tabular}{|c|c|c|c|c|}
\hline Independent Variables & Model One & Model Two & Model Three & Model Four \\
\hline Smokeless Tobacco Tax & $\begin{array}{l}-0.004 \\
(-3.91)\end{array}$ & $\begin{array}{l}-0.004 \\
(-3.59)\end{array}$ & $\begin{array}{l}-0.003 \\
(-2.52)\end{array}$ & $\begin{array}{l}-0.002 \\
(-2.26)\end{array}$ \\
\hline Minimum Purchase Age & & & $\begin{array}{l}-0.212 \\
(-2.02)\end{array}$ & $\begin{array}{l}-0.185 \\
(-1.75)\end{array}$ \\
\hline $\begin{array}{l}\text { Restriction on Distribution of } \\
\text { Free Samples }\end{array}$ & & & $\begin{array}{r}-0.0477 \\
(-2.05)\end{array}$ & $\begin{array}{l}-0.046 \\
(-1.99)\end{array}$ \\
\hline Tobacco Licensing Provisions & & & $\begin{array}{l}-0.187 \\
(-4.79)\end{array}$ & $\begin{array}{l}-0.186 \\
(-4.76)\end{array}$ \\
\hline Minimum Purchase Age Signs & & & $\begin{array}{l}-0.109 \\
(-3.95)\end{array}$ & $\begin{array}{l}-0.103 \\
(-3.72)\end{array}$ \\
\hline Black & $\begin{array}{c}-0.896 \\
(-15.74)\end{array}$ & $\begin{array}{l}-0.967 \\
(-16.54)\end{array}$ & $\begin{array}{l}-0.892 \\
(-15.6)\end{array}$ & $\begin{array}{l}-0.960 \\
(-16.40)\end{array}$ \\
\hline Other Race & $\begin{array}{l}-0.218 \\
(-7.01)\end{array}$ & $\begin{array}{l}-0.250 \\
(-7.82)\end{array}$ & $\begin{array}{l}-0.207 \\
(-6.60)\end{array}$ & $\begin{array}{l}-0.240 \\
(-7.44)\end{array}$ \\
\hline Age & $\begin{array}{l}0.100 \\
(9.47)\end{array}$ & $\begin{array}{l}0.096 \\
(8.96)\end{array}$ & $\begin{array}{l}0.100 \\
(9.47)\end{array}$ & $\begin{array}{l}0.096 \\
(8.98)\end{array}$ \\
\hline Real Weekly Income & $\begin{array}{c}0.004 \\
(14.88)\end{array}$ & $\begin{array}{c}0.004 \\
(10.76)\end{array}$ & $\begin{array}{c}0.004 \\
(14.80)\end{array}$ & $\begin{array}{c}0.004 \\
(10.69)\end{array}$ \\
\hline Grade 8 or 10 & $\begin{array}{l}0.324 \\
(7.14)\end{array}$ & $\begin{array}{l}0.305 \\
(6.56)\end{array}$ & $\begin{array}{l}0.331 \\
(7.26)\end{array}$ & $\begin{array}{l}0.313 \\
(6.70)\end{array}$ \\
\hline Year $=1993$ & $\begin{array}{l}-0.106 \\
(3.62)\end{array}$ & $\begin{array}{l}-0.102 \\
(-3.46)\end{array}$ & $\begin{array}{l}-0.093 \\
(-3.14)\end{array}$ & $\begin{array}{l}-0.090 \\
(-3.03)\end{array}$ \\
\hline Year $=1994$ & $\begin{array}{r}-0.046 \\
(-1.62)\end{array}$ & $\begin{array}{l}-0.042 \\
(-1.48)\end{array}$ & $\begin{array}{l}-0.041 \\
(-1.40)\end{array}$ & $\begin{array}{l}-0.039 \\
(-1.33)\end{array}$ \\
\hline Rural & $\begin{array}{c}0.364 \\
(14.49)\end{array}$ & $\begin{array}{c}0.343 \\
(13.40)\end{array}$ & $\begin{array}{c}0.357 \\
(14.21)\end{array}$ & $\begin{array}{c}0.338 \\
(13.18)\end{array}$ \\
\hline $\begin{array}{l}\text { Infrequent Religious } \\
\text { Attendance }\end{array}$ & $\begin{array}{c}0.014 \\
(0.429)\end{array}$ & $\begin{array}{c}0.032 \\
(0.974)\end{array}$ & $\begin{array}{l}0.011 \\
(0.33)\end{array}$ & $\begin{array}{l}0.028 \\
(0.86)\end{array}$ \\
\hline $\begin{array}{l}\text { Frequent Religious } \\
\text { Attendance }\end{array}$ & $\begin{array}{l}-0.151 \\
(-4.40)\end{array}$ & $\begin{array}{l}-0.101 \\
(-2.90)\end{array}$ & $\begin{array}{l}-0.153 \\
(-4.46)\end{array}$ & $\begin{array}{l}-0.105 \\
(-3.00)\end{array}$ \\
\hline
\end{tabular}




\begin{tabular}{|c|c|c|c|c|}
\hline Independent Variables & Model One & Model Two & Model Three & Model Four \\
\hline Live Alone & & $\begin{array}{l}0.419 \\
(2.54)\end{array}$ & & $\begin{array}{l}0.414 \\
(2.51)\end{array}$ \\
\hline Father Only & & $\begin{array}{l}0.207 \\
(3.65)\end{array}$ & & $\begin{array}{l}0.205 \\
(3.61)\end{array}$ \\
\hline Mother Only & & $\begin{array}{l}0.088 \\
(2.54)\end{array}$ & & $\begin{array}{l}0.090 \\
(2.59)\end{array}$ \\
\hline Other Family Structure & & $\begin{array}{l}0.192 \\
(2.63)\end{array}$ & & $\begin{array}{l}0.192 \\
(2.64)\end{array}$ \\
\hline Siblings & & $\begin{array}{r}-0.012 \\
(-0.41)\end{array}$ & & $\begin{array}{l}-0.007 \\
(-0.26)\end{array}$ \\
\hline $\begin{array}{l}\text { Father Less Than High } \\
\text { School Graduate }\end{array}$ & & $\begin{array}{l}0.140 \\
(3.47)\end{array}$ & & $\begin{array}{l}0.138 \\
(3.43)\end{array}$ \\
\hline $\begin{array}{l}\text { Father More Than High } \\
\text { School Graduate }\end{array}$ & & $\begin{array}{l}-0.064 \\
(-2.29)\end{array}$ & & $\begin{array}{l}-0.062 \\
(-2.19)\end{array}$ \\
\hline $\begin{array}{l}\text { Mother Less Than High } \\
\text { School Graduate }\end{array}$ & & $\begin{array}{l}-0.074 \\
(-1.70)\end{array}$ & & $\begin{array}{l}-0.076 \\
(-1.75)\end{array}$ \\
\hline $\begin{array}{l}\text { Mother More Than High } \\
\text { School Graduate }\end{array}$ & & $\begin{array}{l}-0.046 \\
(-1.70)\end{array}$ & & $\begin{array}{l}-0.046 \\
(-1.73)\end{array}$ \\
\hline Not Single & & $\begin{array}{l}-0.042 \\
(-0.34)\end{array}$ & & $\begin{array}{l}-0.047 \\
(-0.38)\end{array}$ \\
\hline Mother Worked Part-time & & $\begin{array}{l}0.011 \\
(0.31)\end{array}$ & & $\begin{array}{l}0.014 \\
(0.37)\end{array}$ \\
\hline Mother Worked Full-time & & $\begin{array}{l}0.113 \\
(3.73)\end{array}$ & & $\begin{array}{l}0.112 \\
(3.68)\end{array}$ \\
\hline Average Hours Worked & & $\begin{array}{l}0.002 \\
(1.05)\end{array}$ & & $\begin{array}{l}0.002 \\
(1.13)\end{array}$ \\
\hline
\end{tabular}

- All equations also include an intercept. Asymptotic t-ratios are in parentheses. The critical values for the $t$ ratios are $2.58(2.33), 1.96(1.64)$, and $1.64(1.28)$ at the one, five, and ten percent significance levels respectively, based on a two-tailed (one-tailed)test. All equations, based on a Chi-square test of-2*loglikelihood ratio are significant at the one percent significance level. 
Table 4

Smokeless Tobacco Consumption by Users

\begin{tabular}{|c|c|c|c|c|}
\hline Independent Variables & Model One & Model Two & Model Three & Model Four \\
\hline Smokeless Tobacco Tax & $\begin{array}{l}-0.004 \\
(-1.81)\end{array}$ & $\begin{array}{l}-0.004 \\
(-1.57)\end{array}$ & $\begin{array}{l}-0.0025 \\
(-1.04)\end{array}$ & $\begin{array}{l}-0.002 \\
(-0.85)\end{array}$ \\
\hline Minimum Purchase Age & & & $\begin{array}{l}-0.54 \\
(-2.45)\end{array}$ & $\begin{array}{l}-0.463 \\
(-2.11)\end{array}$ \\
\hline $\begin{array}{l}\text { Restriction on Distribution of } \\
\text { Free Samples }\end{array}$ & & & $\begin{array}{l}0.021 \\
(0.41)\end{array}$ & $\begin{array}{l}0.030 \\
(0.56)\end{array}$ \\
\hline Tobacco Licensing Provisions & & & $\begin{array}{l}-0.166 \\
(-2.02)\end{array}$ & $\begin{array}{l}-0.170 \\
(-2.08)\end{array}$ \\
\hline Minimum Purchase Age Signs & & & $\begin{array}{l}-0.065 \\
(-1.08)\end{array}$ & $\begin{array}{l}-0.062 \\
(-1.04)\end{array}$ \\
\hline Black & $\begin{array}{l}-0.475 \\
(-2.81)\end{array}$ & $\begin{array}{l}-0.582 \\
(-3.42)\end{array}$ & $\begin{array}{l}-0.452 \\
(-2.67)\end{array}$ & $\begin{array}{l}-0.559 \\
(-3.28)\end{array}$ \\
\hline Other Race & $\begin{array}{c}0.063 \\
(0.85)\end{array}$ & $\begin{array}{l}0.007 \\
(0.10)\end{array}$ & $\begin{array}{l}0.073 \\
(0.98)\end{array}$ & $\begin{array}{l}0.017 \\
(0.22)\end{array}$ \\
\hline Age & $\begin{array}{l}0.112 \\
(4.58)\end{array}$ & $\begin{array}{l}0.102 \\
(4.17)\end{array}$ & $\begin{array}{l}0.111 \\
(4.54)\end{array}$ & $\begin{array}{l}0.102 \\
(4.15)\end{array}$ \\
\hline Real Weekly Income & $\begin{array}{l}0.004 \\
(5.56)\end{array}$ & $\begin{array}{l}0.003 \\
(3.51)\end{array}$ & $\begin{array}{l}.0035 \\
(5.49)\end{array}$ & $\begin{array}{l}0.003 \\
(3.49)\end{array}$ \\
\hline Grade 8 or 10 & $\begin{array}{l}0.339 \\
(3.44)\end{array}$ & $\begin{array}{l}0.384 \\
(3.83)\end{array}$ & $\begin{array}{l}0.332 \\
(3.36)\end{array}$ & $\begin{array}{l}0.382 \\
(3.80)\end{array}$ \\
\hline Year $=1993$ & $\begin{array}{l}-0.145 \\
(-2.17)\end{array}$ & $\begin{array}{r}-0.126 \\
(-1.89)\end{array}$ & $\begin{array}{c}-0.12 \\
(-1.77)\end{array}$ & $\begin{array}{l}-0.105 \\
(-1.56)\end{array}$ \\
\hline Year $=1994$ & $\begin{array}{r}-0.227 \\
(-3.53)\end{array}$ & $\begin{array}{r}-0.211 \\
(-3.30)\end{array}$ & $\begin{array}{c}-0.21 \\
(-3.19)\end{array}$ & $\begin{array}{r}-0.200 \\
(-3.05)\end{array}$ \\
\hline Rural & $\begin{array}{l}0.357 \\
(6.64)\end{array}$ & $\begin{array}{l}0.320 \\
(5.85)\end{array}$ & $\begin{array}{l}0.353 \\
(6.57)\end{array}$ & $\begin{array}{l}0.318 \\
(5.84)\end{array}$ \\
\hline $\begin{array}{l}\text { Infrequent Religious } \\
\text { Attendance }\end{array}$ & $\begin{array}{r}-0.035 \\
(-0.48)\end{array}$ & $\begin{array}{c}.008 \\
(0.11)\end{array}$ & $\begin{array}{l}-0.042 \\
(-0.58)\end{array}$ & $\begin{array}{l}0.001 \\
(0.01)\end{array}$ \\
\hline $\begin{array}{l}\text { Frequent Religious } \\
\text { Attendance }\end{array}$ & $\begin{array}{l}-0.076 \\
(-0.98)\end{array}$ & $\begin{array}{l}0.015 \\
(0.19)\end{array}$ & $\begin{array}{l}-0.082 \\
(-1.06)\end{array}$ & $\begin{array}{l}0.008 \\
(0.10)\end{array}$ \\
\hline
\end{tabular}




\begin{tabular}{|c|c|c|c|c|}
\hline Independent Variables & Model One & Model Two & Model Three & Model Four \\
\hline Live Alone & & $\begin{array}{l}0.111 \\
(0.37)\end{array}$ & & $\begin{array}{l}0.102 \\
(0.34)\end{array}$ \\
\hline Father Only & & $\begin{array}{l}0.156 \\
(1.31)\end{array}$ & & $\begin{array}{l}0.152 \\
(1.27)\end{array}$ \\
\hline Mother Only & & $\begin{array}{c}-0.02 \\
(-0.26)\end{array}$ & & $\begin{array}{l}-0.012 \\
(-0.15)\end{array}$ \\
\hline Other Family Structure & & $\begin{array}{l}0.003 \\
(0.02)\end{array}$ & & $\begin{array}{l}0.002 \\
(0.01)\end{array}$ \\
\hline Siblings & & $\begin{array}{l}-0.180 \\
(-2.91)\end{array}$ & & $\begin{array}{l}-0.183 \\
(-2.94)\end{array}$ \\
\hline $\begin{array}{l}\text { Father Less Than High } \\
\text { School Graduate }\end{array}$ & & $\begin{array}{l}0.087 \\
(1.02)\end{array}$ & & $\begin{array}{l}0.090 \\
(1.06)\end{array}$ \\
\hline $\begin{array}{l}\text { Father More Than High } \\
\text { School Graduate }\end{array}$ & & $\begin{array}{l}-0.020 \\
(-0.33)\end{array}$ & & $\begin{array}{l}-0.013 \\
(-0.22)\end{array}$ \\
\hline $\begin{array}{l}\text { Mother Less Than High } \\
\text { School Graduate }\end{array}$ & & $\begin{array}{l}0.343 \\
(3.64)\end{array}$ & & $\begin{array}{l}0.335 \\
(3.56)\end{array}$ \\
\hline $\begin{array}{l}\text { Mother More Than High } \\
\text { School Graduate }\end{array}$ & & $\begin{array}{l}-0.051 \\
(-0.86)\end{array}$ & & $\begin{array}{l}-0.054 \\
(-0.92)\end{array}$ \\
\hline Not Single & & $\begin{array}{l}0.880 \\
(3.40)\end{array}$ & & $\begin{array}{l}0.893 \\
(3.44)\end{array}$ \\
\hline Mother Worked Part-time & & $\begin{array}{l}0.030 \\
(0.36)\end{array}$ & & $\begin{array}{l}0.043 \\
(0.52)\end{array}$ \\
\hline Mother Worked Full-time & & $\begin{array}{l}0.115 \\
(1.66)\end{array}$ & & $\begin{array}{l}0.115 \\
(1.67)\end{array}$ \\
\hline Average Hours Worked & & $\begin{array}{l}0.004 \\
(1.27)\end{array}$ & & $\begin{array}{l}0.004 \\
(1.23)\end{array}$ \\
\hline
\end{tabular}

- All equations also include an intercept. Xt-ratiosare in parentheses. The critical values for the $t$-ratios are 2.58 (2.33), 1.96 (1.64), and 1.64 (1.28)at the one, five, and ten percent significance levels respectively, based on a two-tailed (one-tailed)test. All equations, based on an F test, are significant at the one percent significance level. 
Table 5

Estimated Tax and Price Elasticities of Smokeless Tobacco Demand by Young Males

\begin{tabular}{|c|c|c|c|c|}
\hline & Model One & Model Two & Model Three & Model Four \\
\hline \multicolumn{5}{|c|}{ Panel A: Tax Elasticities } \\
\hline $\begin{array}{l}\text { Participation in Smokeless } \\
\text { Tobacco Use }\end{array}$ & -0.066 & -0.061 & -0.043 & -0.039 \\
\hline $\begin{array}{l}\text { Use of Smokeless Tobacco by } \\
\text { Smokeless Tobacco Users }\end{array}$ & -0.044 & -0.038 & -0.026 & -0.021 \\
\hline $\begin{array}{l}\text { Total Elasticity of Smokeless } \\
\text { Tobacco Demand }\end{array}$ & -0.110 & -0.099 & -0.069 & -0.060 \\
\hline \multicolumn{5}{|c|}{ Panel B: Price Elasticities } \\
\hline $\begin{array}{l}\text { Participation in Smokeless } \\
\text { Tobacco Use }\end{array}$ & -0.508 & -0.469 & -0.331 & -0.300 \\
\hline $\begin{array}{l}\text { Use of Smokeless Tobacco by } \\
\text { Smokeless Tobacco Users }\end{array}$ & -0.338 & -0.292 & -0.200 & -0.162 \\
\hline $\begin{array}{l}\text { Total Elasticity of Smokeless } \\
\text { Tobacco Demand }\end{array}$ & -0.846 & -0.762 & -0.531 & -0.462 \\
\hline
\end{tabular}

